\title{
THE EFFECTS OF 5-BROMO-2-THIENYL-ETHYL- KETONE THIOSEMICARBAZONE ON OVARIAN CYCLICITY AND OVULATION IN THE RAT
}

\author{
G. J. SHAAR, D. R. BENNETT, J. G. POWELL, JR, \\ E. B. SMALSTIG, F. C. TINSLEY AND R. L. COGHRANE \\ Lilly Research Laboratories, Eli Lilly and Company, \\ Indianapolis, Indiana 46206, U.S.A.
}

(Received 16th October 1974)

\begin{abstract}
Summary. Pseudopregnant and cyclic rats were injected for 5 to 26 days with daily doses of 5 and/or $3 \mathrm{mg}$ of 5-bromo-2-thienyl-ethyl-ketone thiosemicarbazone (70026) starting on Day 0 (the day of oestrus). The vaginal smear cytology, record of ovulation and ability to breed and conceive were compared with the results for corn oil-injected controls. Both doses of 70026 were found to cause a reappearance of pro-oestrous and/or oestrous vaginal smears within 4 to 6 days in the pseudopregnant rats, but ovulations did not occur. The 5-mg dose of 70026 inhibited ovulation and interrupted the oestrous cycle in cyclic rats, even though the daily 3-mg dose seemed to have little effect on ovulation, ovarian cyclicity, breeding or conception. In spite of the absence of an ovulation accompanying the induced pro-oestrous and/or oestrous vaginal smears in the pseudopregnant rats, the pattern of the vaginal smears suggested the occurrence of a 'delayed pseudopregnancy' in most of the pseudopregnant rats treated daily with $3 \mathrm{mg}$, but in few of those treated with $5 \mathrm{mg}, 70026$.
\end{abstract}

\section{INTRODUCTION}

Work in this laboratory led to the discovery of a series of thiophene thiosemicarbazones that possessed antifertility activity in rats. Two reports (Mason $e t$ al., 1969; Tinsley et al., 1970) have suggested that one of these compounds, 5bromo-2-thienyl-ethyl-ketone thiosemicarbazone (70026), inhibited ovarian progesterone secretion in the rat. Preliminary results indicate that treatment of pseudopregnant and/or pregnant rats with 70026 will cause these animals to display pro-oestrous and/or oestrous vaginal smears within 4 to 5 days (Mason et al., 1969; Tinsley et al., 1970). This suggested that 70026 might be useful for synchronizing oestrus in animals. For this reason, the following series of experiments was designed to determine the incidence and interval to return of prooestrous and/or oestrous vaginal smears in pseudopregnant rats treated with 70026 , to establish whether or not ovulation accompanied these smears, and to resolve whether 70026 had an effect on ovulation in the rat. 


\section{MATERIALS AND METHODS}

The animals used in these experiments were mature virgin female rats of the Carworth CFE and Sprague-Dawley strains weighing 201 to $291 \mathrm{~g}$. They were allowed free access to Purina Laboratory Chow and tap water and were housed individually on a light regimen of $14 \mathrm{hr}$ light $/ 10 \mathrm{hr}$ dark at a temperature of 74 to $76^{\circ} \mathrm{F}$. Daily vaginal smears were taken in the morning and were assessed unstained and fresh. All animals were required to have completed at least three normal 4- to 5-day oestrous cycles immediately before the experiment. Pseudopregnancy was induced by stimulating the cervix with a glass rod on the morning and evening of the last day of oestrus (Day 0). The 70026 was prepared as a suspension in corn oil. This suspension was made up fresh whenever it became discoloured. All injections were given subcutaneously once daily in a volume of $0.1 \mathrm{ml}$. Ergocornine hydrogenmaleate, when used, was dissolved in $70 \%$ ethanol and injected once subcutaneously in a volume of $0.1 \mathrm{ml}$.

\section{Experiment $A$}

Rats were stimulated to become pseudopregnant and the length of the subsequent cycle was determined (i.e. the number of days elapsing between the last day of a vaginal smear consisting predominantly of cornified epithelial cells and the day of a succeeding vaginal smear of predominantly cornified, or nucleated, epithelial cells, which was followed by a predominantly leucocytic smear). Ten animals each were injected daily with $0.1 \mathrm{ml}$ corn oil, $3 \mathrm{mg} 70026$ or $5 \mathrm{mg}$ 70026 from Day 0 to Day 18.

\section{Experiment $B$}

Rats were stimulated to become pseudopregnant and treated daily with $0 \cdot 1$ $\mathrm{ml}$ corn oil, $3 \mathrm{mg} 70026$ or $5 \mathrm{mg} 70026$ from Day 0 to Day 5 or 6 . All rats were killed on the last day of treatment, ten/group on Day 5 and six/group on Day 6 . The contents of the oviducts of these animals were expressed onto microscope slides and dispersed with distilled water. The contents of the uterine horns were flushed onto microscope slides with distilled water. The slides were then air dried, stained with Wright's stain and examined under a microscope for eggs.

\section{Experiment $C$}

Pseudopregnant and cyclic rats were treated daily with $0.1 \mathrm{ml}$ corn oil, $3 \mathrm{mg}$ 70026 or $5 \mathrm{mg} 70026$ from Day 0 to Day 4, 5 or 6 . Each treatment group within reproductive state and treatment interval consisted of five animals. All animals were killed on the last day of treatment and their ovaries were removed, submerged in $0.9 \%$ saline and inspected under a dissecting microscope $(\times 10$ to $\times 30$ magnification) for ovulation craters. The oviducts of these animals were inspected for cumulus mass swellings and the eggs were expelled and then counted under a dissecting microscope $(\times 60$ to $\times 90)$. An additional group of six animals served as positive controls for the technique. These rats were stimulated to become pseudopregnant and were injected with $1 \mathrm{mg}$ ergocornine hydrogenmaleate on Day 1. It was assumed that these animals would return to oestrus and ovulate within 3 to 5 days of the treatment (Shelesnyak, 1957; 
Kraicer \& Shelesnyak, 1965a, b, 1968; Kisch \& Shelesnyak, 1968) and autopsy was, therefore, performed on the day that the rats exhibited an oestrous vaginal smear. Their ovaries were checked for ovulation craters and their oviducts for cumulus masses.

\section{Experiment $D$}

Injections of $0 \cdot 1 \mathrm{ml}$ corn oil or $3 \mathrm{mg} 70026$ were each given daily to 16 cyclic female rats. The injections were started 6 days before caging the females with proven males (Long-Evans strain) and were continued for 1 day after the day of mating. The females were left with the males until they mated or for a maximum period of 20 days. When mating did not occur, treatment was continued for the 20 days of cohabitation. The animals were killed 17 days after mating and the numbers of pregnancies and of live and dead fetuses were noted.

\section{RESULTS}

\section{Experiment $A$}

The results of this experiment appear in Table 1. At both dosages, 70026 was capable of causing the reappearance of a pro-oestrous and/or oestrous vaginal smear within 4 to 6 days in rats that were stimulated to become pseudopregnant.

Table 1. Effects of compound 70026 on cycle length, as judged by the vaginal smear, in rats stimulated to become pseudopregnant

\begin{tabular}{lccc}
\hline \multirow{2}{*}{$\begin{array}{c}\text { Treatment* (Day 0 } \\
\text { to Day 18) }\end{array}$} & No. of animals & \multicolumn{2}{c}{ Cycle length (days) } \\
\cline { 3 - 4 } & & First cycle & Second cycle \\
\hline Corn oil $(0 \cdot 1 \mathrm{ml} /$ day $)$ & 10 & 14 to 16 & - \\
$70026(3 \mathrm{mg} /$ day $)$ & $2 \ddagger$ & 5 & 4 \\
& $8 \ddagger$ & 4 to 6 & 9 to $12 \S$ \\
$70026(5 \mathrm{mg} /$ day) & 5 & 5 to 6 & 3 to 5 \\
& $4 \ddagger$ & 5 to 6 & 7 to 11 \% \\
& 1 & 10 & 5 \\
\hline
\end{tabular}

* The cervix of each rat was stimulated with a glass rod in the morning and afternoon of the last day of an oestrous vaginal smear (Day 0 ).

$\uparrow$ These two animals exhibited an oestrous vaginal smear for 1 additional day after the start of treatment (i.e. on Day l).

$¥$ One rat exhibited an oestrous vaginal smear for one additional day after the start of treatment (i.e. on Day 1).

$\$$ One rat was killed on the 13 th day of the second cycle before exhibiting an oestrous vaginal smear.

If One rat with an 11-day cycle exhibited an oestrous vaginal smear for 5 consecutive days out of the 11 .

It was assumed that the two animals in the group treated with $3 \mathrm{mg} 70026$ that exhibited an oestrous vaginal smear on the day after the start of treatment, reacted to stimulation of the cervix in a manner similar to that of rats that exhibited a dioestrous vaginal smear. These two animals were classified separately from the rest in the group only on the basis of the length of their second cycle. Most of the rats given the dose of $3 \mathrm{mg} 70026$ exhibited a prolonged 
second cycle after the shortened first cycle (i.e. apparent 'delayed pseudopregnancies'; Everett, 1967). By contrast, less than half of the animals given 5 mg 70026 displayed a prolonged second cycle and one of those rats that did had an apparently abnormal cycle which was manifest as persistent cornification of the vaginal epithelium.

\section{Experiment $B$}

The results of this experiment are presented in Table 2. The data support the results of Exp A. Unexpectedly, eggs were recovered from the oviducts and/or uteri of $4 / 10$ control animals on Day 5 of pseudopregnancy. No eggs, however, were found in the genital tract of the one control animal exhibiting a return to a pro-oestrous vaginal smear. Eggs were recovered on Day 5 from four of the animals receiving $3 \mathrm{mg} 70026$ and three of these animals exhibited a reappearance of a pro-oestrous and/or oestrous vaginal smear. Three of the five animals that had eggs after treatment with $5 \mathrm{mg} 70026$ and were killed on Day 5 exhibited the reappearance of a pro-oestrous and/or oestrous vaginal smear, but such smears were not obtained from the two animals that had eggs in the uterus on Day 6. All of the eggs recovered in this experiment appeared to be shrunken and in poor condition.

Table 2. Effect of compound 70026 on recovery of eggs from rats stimulated to become pseudopregnant

\begin{tabular}{lccccccc}
\hline $\begin{array}{c}\text { Treatment* (Day 0 to } \\
\text { day of autopsy) }\end{array}$ & $\begin{array}{c}\text { No. of } \\
\text { animals }\end{array}$ & $\begin{array}{c}\text { Day of } \\
\text { autopsy }\end{array}$ & $\begin{array}{c}\text { No. of animals with } \\
\text { a return to an oestrous } \\
\text { or pro-oestrous vaginal } \\
\text { smear }\end{array}$ & \multicolumn{2}{c}{ No. of animals with eggs } \\
\hline Corn oil (0.1 ml/day) & 10 & 5 & 1 & $2(4)$ & $2(5)$ & 4 \\
& 6 & 6 & 0 & $0(0)$ & $0(0)$ & 0 \\
70026 (3 mg/day) & 10 & 5 & 6 & $1(2)$ & $4(23)$ & 4 \\
& 6 & 6 & 4 & $0(0)$ & $0(0)$ & 0 \\
70026 (5 mg/day) & 10 & 5 & 8 & $0(0)$ & $5(18)$ & 5 \\
& 6 & 6 & 3 & $0(0)$ & $2(18)$ & 2 \\
\hline
\end{tabular}

* The cervix of each rat was stimulated with a glass rod in the morning and afternoon of the last day of an oestrous vaginal smear (Day 0 ).

+ Number of eggs in parentheses.

\section{Experiment $C$}

The results shown in Table 3(a), again support the results of Exp A. Ovulation rarely accompanied the reappearance of pro-oestrous and/or oestrous vaginal smears in the animals treated with 70026 . Only two ovulation craters were noted in each of the three animals that had craters, and these may have been caused by accidental rupture of follicles at autopsy. Large unruptured follicles were present in the ovaries of the rat receiving $5 \mathrm{mg} 70026$ and killed on Day 5.

The results concerning the cyclic animals appear in Table $3(\mathrm{~b})$. Only $2 / 5$ control animals that were killed on Day 4 exhibited the reappearance of an 
Table 3. Effects of compound 70026 on ovulation in rats

\begin{tabular}{|c|c|c|c|c|c|c|}
\hline \multirow{2}{*}{\multicolumn{2}{|c|}{$\begin{array}{l}\text { Treatment (Day } 0 \text { to } \\
\text { day of autopsy) }\end{array}$}} & \multirow{2}{*}{$\begin{array}{c}\text { No. of } \\
\text { animals }\end{array}$} & \multirow{2}{*}{$\begin{array}{l}\text { Day of } \\
\text { autopsy }\end{array}$} & \multirow[b]{2}{*}{$\begin{array}{l}\text { No. of animals with } \\
\text { a return to an oestrous } \\
\text { or pro-oestrous vaginal } \\
\text { smear }\end{array}$} & \multicolumn{2}{|c|}{ No. of females } \\
\hline & & & & & $\begin{array}{l}\text { With an observable } \\
\text { cumulus mass in the } \\
\text { oviducts }\end{array}$ & $\begin{array}{l}\text { With ovulation } \\
\text { craters in the } \\
\text { ovaries } \ddagger\end{array}$ \\
\hline \multirow[t]{3}{*}{ (a) } & $\begin{array}{l}\text { Pseudopregnant rats* } \\
\text { Corn oil } \\
(0.1 \mathrm{ml} / \mathrm{day})\end{array}$ & $\begin{array}{l}5 \\
5 \\
5\end{array}$ & $\begin{array}{l}4 \\
5 \\
6\end{array}$ & $\begin{array}{l}0 \\
0 \\
0\end{array}$ & $\begin{array}{l}0(0) \\
0(0) \\
0(0)\end{array}$ & $\begin{array}{l}0(0) \\
0(0) \\
0(0)\end{array}$ \\
\hline & $\begin{array}{l}70026 \\
\text { (3 mg/day) }\end{array}$ & $\begin{array}{l}5 \\
5 \\
5\end{array}$ & $\begin{array}{l}4 \\
5 \\
6\end{array}$ & $\begin{array}{l}3 \\
5 \\
5\end{array}$ & $\begin{array}{l}0(0) \\
0(0) \\
0(0)\end{array}$ & $\begin{array}{l}0(0) \\
1(2) \\
0(0)\end{array}$ \\
\hline & $\begin{array}{l}70026 \\
(5 \mathrm{mg} / \text { day })\end{array}$ & $\begin{array}{l}5 \\
5 \\
5\end{array}$ & $\begin{array}{l}4 \\
5 \\
6\end{array}$ & $\begin{array}{l}5 \\
5 \\
3\end{array}$ & $\begin{array}{l}0(0) \\
0(0) \\
0(0)\end{array}$ & $\begin{array}{l}1(2) \\
1(2) \\
0(0)\end{array}$ \\
\hline (b) & $\begin{array}{l}\text { Cyclic rats } \dagger \\
\text { Corn oil } \\
(0 \cdot 1 \mathrm{ml} / \text { day })\end{array}$ & $\begin{array}{l}5 \\
5 \\
5\end{array}$ & $\begin{array}{l}4 \\
5 \\
6\end{array}$ & $\begin{array}{l}2 \\
5 \\
4\end{array}$ & $\begin{array}{l}2(18) \\
4(36) \\
0(0)\end{array}$ & $\begin{array}{l}2(17) \\
5(29) \\
3(21)\end{array}$ \\
\hline & $\begin{array}{l}70026 \\
(3 \mathrm{mg} / \mathrm{day})\end{array}$ & $\begin{array}{l}5 \\
5 \\
5\end{array}$ & $\begin{array}{l}4 \\
5 \\
6\end{array}$ & $\begin{array}{l}5 \\
5 \\
5\end{array}$ & $\begin{array}{l}4(38) \\
1(9) \\
1(4)\end{array}$ & $\begin{array}{l}5(42) \\
3(25) \\
1(2) \S\end{array}$ \\
\hline & $\begin{array}{l}70026 \\
(5 \mathrm{mg} / \text { day })\end{array}$ & $\begin{array}{l}5 \\
5 \\
5\end{array}$ & $\begin{array}{l}4 \\
5 \\
6\end{array}$ & $\begin{array}{l}3 \\
2 \\
5\end{array}$ & $\begin{array}{l}1(11) \\
1(4) \\
0(0)\end{array}$ & $\begin{array}{l}1(8) \\
1(2) \\
2(13)\end{array}$ \\
\hline
\end{tabular}

* The cervix of each rat was stimulated with a glass rod in the morning and afternoon of the last day of an oestrous vaginal smear (Day 0 ).

$\dagger$ Day $0=$ last day of an oestrous vaginal smear.

$\$$ Number of eggs and number of ovulation craters in parentheses.

$\$$ This rat was not the same as the one with eggs in the oviducts.

oestrous vaginal smear. The other three animals all exhibited pro-oestrous vaginal smears at autopsy, indicating that they were experiencing 5-day cycles. The number of control animals in which ovulation craters were found agrees with the number exhibiting the reappearance of a full oestrous vaginal smear, except in the rats killed on Day 6. One of these rats displayed an oestrous vaginal smear on Day 4, but did not exhibit ovulation craters on Day 6. The discrepancy between the numbers of rats with cumulus masses and those with ovulation craters was probably the result of the masses dispersing before the craters had disappeared. Daily dosage with $3 \mathrm{mg} 70026$ did not inhibit ovulation or the vaginal smear cycle, but daily treatment with $5 \mathrm{mg}$ inhibited both ovulation and the vaginal smear cycle, the effect being greater on ovulation.

All six of the pseudopregnant animals treated with ergocornine hydrogenmaleate exhibited a full oestrous vaginal smear at autopsy on Day 5. Every animal had ovulation craters in the ovaries and cumulus masses in the oviducts. Forty-four ovulation craters and 60 eggs were found.

\section{Experiment $D$}

Fifteen of the sixteen rats treated daily with $3 \mathrm{mg} 70026$ mated, whereas only 12/16 control animals did. Twelve of the animals in each group were pregnant 
at autopsy 17 days after mating. The rats treated with 70026 had a total of 136 embryos, of which 110 were alive. The controls, by comparison, had 175 embryos, of which 162 were alive.

\section{DISGUSSION}

The results from Exps A, B and C clearly demonstrate that 70026 was capable of causing the reappearance of a pro-oestrous and/or oestrous vaginal smear in pseudopregnant rats within 4 to 6 days. The results of Exp. B concerning the occurrence of ovulation in association with these pro-oestrous and/or oestrous vaginal smears in 70026-treated animals were equivocal. They suggested that eggs were often retained for as long as 5 days in pseudopregnant rats. They further suggested that treatment with 70026 caused prolonged retention of eggs, thus negating the use of the presence of eggs as evidence for recent ovulation. Experiment $\mathrm{C}$ was an attempt to answer this same question concerning ovulation by using the presence of ovulation craters, rather than the presence of eggs, as evidence for recent ovulation. The results obtained in the pseudopregnant and cyclic control rats and the pseudopregnant rats treated with ergocornine hydrogenmaleate demonstrated that the presence of ovulation craters was indeed an accurate indicator of the recent occurrence of ovulation. Lincoln \& Kelly (1972), likewise, found this to be the case, since they consistently matched the number of ovulation craters in rats with the number of eggs recovered from the oviducts (W. A. Kelly, personal communication). The results of Exp. G thus show that ovulation was not usually associated with the reappearance of pro-oestrous and/or oestrous vaginal smears induced by treatment with 70026 in pseudopregnant rats. They further suggest that the daily dose of $5 \mathrm{mg} 70026$ inhibited both ovulation and the vaginal cycle in cyclic rats, while the 3-mg dose inhibited neither.

The disruption of the oestrous cycle caused by the daily 5-mg dose of 70026 is not clearly understood. It may have been due to inhibition of steroidogenesis (Lipner \& Greep, 1971; Ying \& Greep, 1971) or to a non-specific effect of the high dose of 70026 . Treatment with 70026 did seem to depress body weight (i.e. the ranges for the average changes in body weight of the groups were: control, $+21 \cdot 1$ to $-6 \cdot 2 \mathrm{~g} ; 3 \mathrm{mg} 70026,+9 \cdot 5$ to $-14.4 \mathrm{~g}$ and $5 \mathrm{mg} 70026,+6 \cdot 1$ to $-20 \cdot 8 \mathrm{~g}$ ). The mortality rate in this series of experiments, however, was fairly low (3/134 animals treated with 70026) and did not seem to be related to the dose or duration of treatment.

The results from Exp. D suggest that the effects of a daily dose of $3 \mathrm{mg} \mathrm{70026,}$ or less, on ovarian cyclicity in pseudopregnant rats, as judged by the vaginal smears, were specific. The fact that the majority of the treated animals could mate, ovulate and conceive indicates that this dose of the compound exhibited little toxicity. Some of the body weight loss, or reduction in gain, could be partly attributed to 70026 inducing a domination of oestrogen, as shown by cornification of the vaginal epithelium in the treated animals. Brobeck $e t$ al. (1947) found that rats lost as much as $12 \mathrm{~g}$ in body weight when they came into oestrus, while they gained as much as $20 \mathrm{~g}$ over the first 7 days of pseudopregnancy. 
The reason for the failure of ovulation to accompany the pro-oestrous and/or oestrous vaginal smears induced in pseudopregnant rats by treatment with 70026 is not known. It was assumed that the effect of 70026 on the vaginal smear was due to suppression of ovarian progesterone secretion (Mason et al., 1969; Tinsley et al., 1970), since 70026 does not seem to have intrinsic oestrogenic activity (Tinsley et al., 1970). This assumption fits well with the fact that a number of the rats treated with 70026 in Exp. A exhibited vaginal smear patterns resembling those of 'delayed pseudopregnancy', just as do pseudopregnant rats treated with ergocornine (Kraicer \& Shelesnyak, 1968) or subjected to ablation of CL (Smalstig et al., 1971). These two procedures to reduce progesterone secretion in the pseudopregnant rat, however, result in ovulation as well as the appearance of pro-oestrous and/or oestrous vaginal smears (Kraicer \& Shelesnyak, 1968; Kraicer, 1969; Smalstig et al., 1971). The results of Mason et al. (1969) suggest that 70026 may not completely suppress the ovarian progesterone secretion in the rat, while the report of Kraicer (1969) suggests that suppression of vaginal cornification in the rat requires more endogenous progesterone than does suppression of ovulation. This would indicate that 70026, at the doses used, did not reduce progesterone secretion enough in the pseudopregnant rat to allow ovulation to occur, but did lower it enough to permit some follicular development and vaginal cornification.

\section{ACKNOWLEDGMENTS}

We should like to thank Dr W. A. Kelly, Department of Anatomy, Medical School, University of Bristol, Bristol, for showing us the technique of checking for recent ovulation by observing and counting ovulation craters and for his helpful criticisms of the manuscript. We also thank Dr R. L. Elton, Sandoz Pharmaceuticals, Hanover, New Jersey, for the generous gift of ergocornine hydrogenmaleate used in this study and Mr R. Edie (Eli Lilly \& Company) for supplying the 5-bromo-2-thienyl-ethyl-ketone thiosemicarbazone.

\section{REFERENCES}

Brobegk, J.R., Wheatland, M. \& Strominger, J.L. (1947) Variations in regulation of energy exchange associated with estrus, diestrus and pseudopregnancy in rats. Endocrinology 40, 65-72.

Everetr, J.W. (1967) Provoked ovulation or long-delayed pseudopregnancy from coital stimuli in barbiturate-blocked rats. Endocrinology 80, 145-154.

Kisch, E.S. \& ShelesnYak, M.C. (1968) Studies on the mechanism of nidation. XXXI. Failure of ergocornine to interrupt gestation in the rat in the presence of foetal placenta. 7 . Reprod. Fert. $15,401-407$.

Kraicer, P.F. (1969) Studies on the effect of nidation. XXXV. Effect of removal of corpora lutea on ovo-implantation and pregnancy in the rat. $\mathcal{F}$. Reprod. Fert. 18, 75-80.

Kraicer, P.F. \& SHELESNYAK, M.C. (1965a) Studies on the mechanism of nidation. XIII. The relationship between chemical structure and biodynamic activity of certain ergot alkaloids. 7 . Reprod. Fert. 10, 221-226.

Kraicer, P.F. \& Shelesnyak, M.C. (1965b) Studies on the mechanism of nidation. XVI. Induction of oestrus by suppression of progesterone secretion by ergocornine. Acta endocr., Copenh. 49, 299-304.

KRAicer, P.F. \& Shelesnyak, M.G. (1968) Interruption of pregnancy, induction of ovulation and delayed pseudopregnancy following suppression of luteal function. Acta endocr., Copenh. 58, 251260.

Lincoln, D.W. \& Kelly, W.A. (1972) The influence of urethane on ovulation in the rat. Endocrinology 90, 1594-1599. 
LIPNER, H. \& GREEP, R.O. (1971) Inhibition of steroidogenesis at various sites in the biosynthetic pathway in relation to induced ovulation. Endocrinology 88,602-607.

Mason, N.R., Tinsley, F.G. \& Cochrane, R.L. (1969) Effect of prolactin and 5-bromo-2-thienylethyl ketone thiosemicarbazone on ovarian progestin levels in the rat. Endocrinology 85, 831-836.

Shelesnyak, M.C. (1957) III. Aspects of reproduction. Some experimental studies on the mechanism of ova-implantation in the rat. Recent Prog. Horm. Res. 13, 269-317.

Smalstig, E.B., Bennett, D.R., ShaAr, G.J. \& Cochrane, R.L. (1971) Effects of corpus luteum removal on ovarian cyclicity of the rat. Endocrinology 89, 714-721.

Tinsley, F.G., Rathmacher, R.P. \& Cochrane, R.L. (1970) The effect of 5-bromo-2-thienyl-ethyl ketone thiosemicarbazone on the induced deciduomal response in the rat. $\mathcal{7}$. Reprod. Fert. 21, 233-241.

Ying, S.-Y. \& GreeP, R.O. (1971) Prevention of aminoglutethimide phosphate (AGP) block of ovulation in PMS-treated immature rats. Proc. Soc. exp. Biol. Med. 136, 916-919. 